\title{
Bannayan Syndrome
}

National Cancer Institute

\section{Source}

National Cancer Institute. Bannayan Syndrome. NCI Thesaurus. Code C3939.

A genetic syndrome caused by mutations in the PTEN gene. It is characterized by macrocephaly and the presence of hamartomas. 